\title{
SELECTION OF PROCUREMENT SYSTEMS IN THE SOUTH AFRICAN CONSTRUCTION INDUSTRY: AN EXPLORATORY STUDY
}

\author{
W.D Thwala: Faculty of Engineering and the Built Environment, University of Johannesburg \\ M.D Mathonsi: Faculty of Engineering and the Built Environment, University of Johannesburg
}

\begin{abstract}
Purpose of this paper: Procurement systems are vital in ensuring the successful implementation of construction projects precisely in all the phases of any particular project. Therefore, this paper aims to investigate in a systematic manner the factors that influence the selection of a procurement system in the South African construction industry.
\end{abstract}

Research methodology: An extensive theory and literature review of procurement systems was conducted. The literature reviewed included a sample of case studies of procurement systems successfully implemented in completed building and civil engineering projects in South Africa. A questionnaire using a four-round Delphi survey method was used to conduct the empirical study in order to obtain participants' opinions about factors influencing the selection of procurement systems as well as the utility value of various procurement systems on each factor as identified. Finally, data analysis of both qualitative and quantitative techniques was performed using the Statistical Package for Social Sciences (SPSS).

Findings: After qualitative analysis, findings of the literature reviewed suggest that factors that influence the selection of procurement systems cut across all the phases of the project as identified in this paper. Therefore, these factors are categorically classified into internal and external factors. Factors from the internal environment were further classified into client characteristics and project characteristics, with client characteristics comprising of variables such as clients' level of knowledge and control, political and social consideration, familiarity of procurement systems, competition, funding arrangement, government public/private sector projects and risk allocation whereas project characteristics comprise of factors (variables) such as size and technical complexity of the project, influence of the project life cycle, expedited project delivery, time, quality and price certainty. Factors from the external environment include variables such as market competition, information technology, regulatory environment, natural causes and globalisation.

Research limitations: In terms of its scope this study focused on both national and international literature reviews and the empirical survey of this study was conducted within South Africa. Its target participants were limited to civil engineers, quantity surveyors, construction/project managers, architects and contractors located in three provinces of South Africa, namely Gauteng, Mpumalanga and Limpopo Provinces.

Value: This study investigates factors that influence the selection of procurement systems in South Africa for the purpose of assisting and guiding construction practitioners in selecting suitable procurement systems for their planned projects.

Conclusion: This study demonstrated that due to changes in the construction industry both factors from the internal and external environments such as size and complexity of construction projects, macro and micro economic conditions, political and social and information technology prevailing, traditional procurement method need to be supplemented with contemporary procurement systems in order to meet the new demands of the industry.

Keywords - procurement systems, traditional, non-traditional, construction projects, South Africa, internal and external factors

\section{INTRODUCTION}

To some extent, procurement systems are not foreign to the South African construction industry. Two studies conducted within the SADC region, one for South Africa and the other for Botswana by Rwelamila and Meyer (1996) have revealed that South Africa had adopted a ready-made construction framework including the hybrids of traditional procurement systems during the years when South Africa was a British colony. Although the South African procurement system is based on the British model, the context and the application of this model were unsystematic for the then apartheid South Africa: this was due to the different set-up and institutional arrangements between South Africa and Britain.

However, the political uncertainties that had taken place during the early 1980 s and late 1990 s led to some changes within the South African construction industry. This was due to the South African construction industry shifting its focus from a predominantly first-world oriented construction environment to a developing-world construction environment that focuses on the basic needs of the population and its economic circumstances. Among other things, this shift was directed towards the development of new construction policies aimed at promoting stability; fostering economic growth and 
economic competitiveness; creating new sustainable employment; as well as addressing the historic imbalances as new industry capacity is being generated for development (Department of Public Works, May 1999).

Post-1994, the newly formed South African Government of National Unity and all stakeholders of the construction industry headed by the Department of Public Works, initiated and co-ordinated the development of the Construction Industry Development Board (CIDB) which was mandated, among other things, to improve a standardised application of best practice in construction procurement within the framework of government procurement policy (Construction Procurement Library, CIDB, 2005). Therefore, this study aims to investigate in a systematic manner the factors that influence the selection of procurement systems within the South African construction industry.

\section{RESEARCH METHODOLOGY}

The triangulation approach was deemed appropriate to investigate factors influencing the selection of procurement systems in the South African construction industry. Triangulation is the combination of two or more methodologies to study the same phenomena (Mathonsi and Thwala (2012). However, triangulation can be conducted in two different approaches, namely simultaneous and sequential triangulation. In conducting this study, the sequential triangulation approach was adopted, which involves linking qualitative and quantitative approaches. The vast body of theory and literature reviews focusing on both national and international literature was used for the qualitative approach in this study. This also included a review of six South African case studies of completed construction projects that had successfully used and implemented universal procurement systems.

For the quantitative approach, self-administered questionnaires through the utilisation of the Delphi survey method were used during the empirical survey for collection opinions. The sample comprised a total of 40 areas of expertise, with ten members representing each of the four professional bodies of the built environment, namely the SACQSP, SACCPMP, SACAP and ECSA. The study was limited to only three provinces of South Africa, namely Gauteng, Mpumalanga and Limpopo Provinces. The Round 1 questionnaire of the Delphi method comprised Sections $A$ and $B$ and was sent to participants sequentially, with Section A first and Section B second. Twenty-one participants, equivalent to $52.5 \%$, completed the questionnaires. The purpose of Section A was to obtain the factual biographical data profiles of the targeted respondents, and to ascertain the participant's level of knowledge about the procurement systems used in South Africa. The purpose of Section B was to determine whether the factors as revealed from the literature review existed within the South African construction industry.

Round 2 of the Delphi survey method comprised a total of 20 variables (factors) collected from Section $B$ of Round 1. Fifteen variables (factors) were found to be from the internal environment and 5 variables (factors) from the external environment. Questionnaires were distributed through electronic mail to 21 participants in Round 2 and all 21 participants completed the questionnaires. All the variables (artificial factors) were subjected to factor analysis for the purpose of obtaining the genuine smaller quantity of factors. Round 3 of the Delphi survey method consisted of 5 factors retained after factor analysis of Round 2, whereby experts were requested to rate the utility value score of each of the 5 factors. Twenty questionnaires were returned, which equates to $50 \%$. Round 4 of the Delphi survey method also consisted of the 5 factors retained from factor analysis of Round 2 for reassessment of Round 3 scores to obtain the mean utility scores on each of the 5 factors. Out of 20 $(50 \%)$ questionnaires sent, 6 participants $(30 \%)$ returned their questionnaires and the other 14 participants $(70 \%)$ did not return their questionnaires; therefore, their scores for Round 3 were considered for Round 4. All the questionnaires from Round 1 to Round 4 were distributed to the participants using electronic mail. Data analyses of both qualitative and quantitative techniques were performed using the Statistical Package for Social Sciences (SPSS).

\section{LITERATURE REVIEW OF PROCUREMENT SYSTEMS}

Based on the literature review conducted around the topic of procurement systems, the author acknowledges that there is a proliferation of terms being utilised by many researchers and practitioners of the construction industry. Some of the terms considered synonymous with procurement systems include terms such as project approach, procurement delivery methods, project delivery systems and contractual arrangements. Therefore, for the purpose of this study, the term procurement system has been adopted as a contemporary term to refer to all the terms synonymous with it. 
Below are the 4 definitions that best define a procurement system:

- It is an organisational structure adopted by the client for the implementation and at times eventual operation of a project (Masterman, 2002).

- It is a key means through which the clients create the pre-conditions for the successful achievement of project-specific objectives (Rameezdeen and Ratnasabapathy, 2006).

- It is the acquisition of project resources for the realisation of a constructed facility (Walker and Rowlinson, 2008).

- It is an organisational system that assigns specific responsibilities and authorities to people and organisations, and defines the relationship of the various elements in the construction industry (Love, Skitmore and Earl, 1998).

According to the Office of Government Commerce (2003) as cited by Leadra, Austeng, Haugen and Klakegg (2006) the procurement systems (routes) deliver the procurement strategy or what the author can refer to as the procurement process, which according to the author is a key factor in determining the success or failure of any particular project. Leadra, Austeng, Haugen and Klakegg (2006) highlight the fact that even though terminologies used in the description of procurement systems differ from one country to the other, the recommended practice for selection of the procurement systems is almost the same across country boundaries.

With a plethora of different procurement systems from which to choose to deliver diverse construction projects, an extensive literature review on procurement systems indicates that there is currently no systematic and no realistic approach applied or used to select the appropriate procurement system; in fact, the literature reviewed further highlighted that factors that influence the selection of procurement systems cut across all the project phases identified in this study. This situation is further exacerbated by the poor contractual relationship between the parties to the contract. The procurement management knowledge includes the techniques to acquire the goods and services from contractors and suppliers, outside of the project organisation (Burke, 2010). Procurement is a process that involves two parties with different objectives who interact in a given market segment (Kerzner, 2006). Procurement systems are basically classified into traditional and non-traditional systems:

Traditional procurement systems - This method is called 'traditional' because it has been in existence for a long time and has been the only choice available for most clients of the construction industry for many years. Using this method, the client enters into an agreement with the design consultant (an architect or engineer) to actually carry out the design work and prepare contract documents. Following the completion of this phase, the contractor is then appointed based upon the owner's criteria and the owner enters into a contract with the successful contractor for the assembly of the project elements. In essence, the client is under two contractual obligations, namely the design professional and the contractor. According to Bennet (2003) in order for the client to obtain a constructed facility, tenders from this type of procurement systems are invited in one of the three following methods:

Open tendering - This is a procedure that allows practically any contractor to submit a tender for the work. This procedure involves either the client or consultant (on behalf) of the client placing a public advertisement giving a brief description of the work. Normally the client will require a cash deposit when contract documents are requested (Pilcher, 1992).

Selective tendering - It consists of the client drawing up a short-list of contractors that are known to have the appropriate qualifications to carry out the work satisfactorily. Those contractors who seek to be listed are then asked for further details concerning their technical competence, financial standing, resources at their disposal and relevant experience. Pre-qualifying contractors who are on the list are invited to tender (Pilcher, 1992). The selection of designers (that is architects and engineers) is usually based on a combination of track record, fees, conceptual design, and previous working relations (Tan, 2007).

Negotiated tendering - This method is applied in several or different contexts, but the essence is that tenders are obtained by the client inviting a single contractor of his/her choice to submit a tender for a particular project (ISO/DIS 10845-1, International Organization for Standardization (ISO), 2008).

Non-traditional procurement systems - This is a diversified contemporary procurement system that not only considers design and construction, but also considers financing, operating and facility management (Masterman, 2002). 
The author is of the opinion that the term 'non-traditional' be used as a generic term for the purpose of this study to refer to all emerging or contemporary procurement systems in the construction industry other than the traditional procurement system. Over the past 50 odd years, the construction industry has undergone changes in a manner never seen before; these changes have led to the development or spread of alternative procurement systems other than the famous traditional route (Royal Institute of British Architects (RIBA) 2000. This can also be evidenced by increased size and complexity of the construction projects, financial challenges, political and social considerations, the impact of changes in information technology and associated changes in work organisation, to mention just some of the changes that have been taking place.

Lam, E.W.M., Chan, A.P.C. and Chan, D.W.M. (2008) believe that the non-traditional procurement system is proving to be successful in overcoming the hurdles inherent within the traditional procurement system. However, despite the positive attributes associated with the non-traditional procurement system, it is still insufficiently sophisticated to enable a final conclusion as to what are the appropriate procurement systems for a building project (Masterman, 2002). Listed below are the three different types of non-traditional procurement systems:

Integrated procurement system - Where one organisation, usually but not exclusively the contractor, takes responsibility for the design and construction of the project, in theory at least. The client deals with only one organisation.

Management-oriented procurement system - under a management-oriented procurement system, the management of the project is carried out by an organisation working with the designer and other consultants to produce the designs and to manage the physical operations which are carried out by contractors. When using systems within this category, the client will need to have a greater involvement with the project than when employing any of the other methods described in the categories listed above and below.

Collaborative/discretionary procurement system - Under a collaborative system the client lays down a framework for the overall administration of the project within which he/she has the discretion to use the most appropriate of all the procurement systems contained within the other three categories. In a collaborative procurement system quantity surveyors play an integral role by providing a wide range of services, which include contractual issues; it also offers quantity surveyors an opportunity to act as independent advisors within the system (Cartlidge, 2002).

\section{South African Perspectives}

Although the forerunner of procurement systems in South Africa is based on the British model, post1994, the South African Government and all other stakeholders of the construction industry through the Department of Public Works, initiated and co-ordinated the development of a comprehensive CIDB as part of their contribution to the national project for Reconstruction, Growth and Development typified in the White Paper: 'Creating an Enabling Environment for Reconstruction, Growth and Development in the Construction Industry' (DPW, 1999).

\section{Construction procurement policy in South Africa}

Procurement is defined as the process which creates, manages and fulfils construction contracts. It is further described as a succession of logically related actions occurring or performed in a definite manner, and which culminate in the completion of a major deliverable or the attainment of a milestone. Processes, in turn, are underpinned by methods (i.e. a documented systematically-ordered collection of rules or approaches) and procedures (i.e. the formal steps to be taken in the performance of a specific task), which are informed and shaped by the policy of an organisation (Draft International Standard ISO/DIS 10845-1, International Organization for Standardization (ISO), 2008). Within the South African Government context, policy is often translated into rules and regulations; policy also relates to choices made in the use of generic procedures, methods and circumstances under which any particular procedure should be used (SANS 294:2004, South African National Standards (SANS) (2004). Therefore it can be deduced from the two above-mentioned definitions that the combination results in a process referred to as a procurement policy, which is defined as a process which creates, and manages contracts based on the choices made in the use of generic procedures, methods and circumstances adopted in terms of 76(4) (c) of the Public Finance Management Act 1999 (National Treasury PPP Unit (2003)). 
In the field of procurement systems, South Africa, like many other developing countries, uses the generic procedures and the standard set of processes and methods for procurement systems that are fair, equitable, transparent, competitive and cost-effective when pursuing implementation of construction projects within the construction industry and this is regulated in all spheres of government including state-owned enterprises through various pieces of legislation (CIDB, 2005).

\section{Procurement systems used in South Africa}

It therefore follows that South Africa, being one of the developing countries, is guided by the framework for developing effective procurement systems in developing countries (The Round Table Process, December 2004). Based on this declaration an agreement was reached for developing countries to utilise common strategies, approaches and tools in order to strengthen the procurement systems' capacities in developing countries and move towards greater reliance on national systems. With reference to SANS 294:2004 (South African National Standards (SANS) (2004) as highlighted in the construction procurement processes, procedures and methods of the best practice guidelines \# A1 (CIDB, September 2005), it provides guidance classified into three categories as shown below in Table 1.

Table 1: Standard procurement procedures in South Africa

\begin{tabular}{|c|c|c|}
\hline Category & $\begin{array}{l}\text { Procurement } \\
\text { procedure }\end{array}$ & Actions \\
\hline 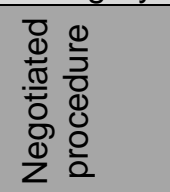 & $\begin{array}{l}\text { Negotiated } \\
\text { procedure }\end{array}$ & A tender offer is solicited from a single tenderer \\
\hline \multirow{7}{*}{ 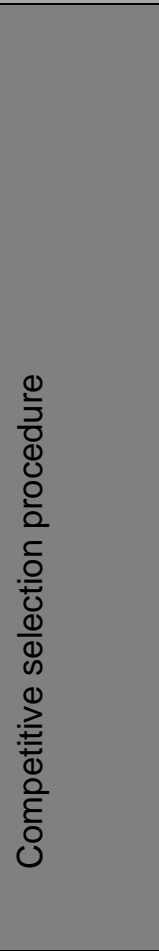 } & $\begin{array}{l}\text { Nomination } \\
\text { procedure }\end{array}$ & $\begin{array}{l}\text { Tenders that satisfy prescribed criteria are entered into an } \\
\text { electronic database. Tenderers are invited to submit tender offers } \\
\text { based on search criteria and if their position is relevant on } \\
\text { database. Tenderers are repositioned on the database upon } \\
\text { appointment or upon submission of tender offer. }\end{array}$ \\
\hline & $\begin{array}{l}\text { Open } \\
\text { procedure }\end{array}$ & $\begin{array}{l}\text { Tenderers may submit tender offers in response to an } \\
\text { advertisement }\end{array}$ \\
\hline & $\begin{array}{l}\text { Proposal } \\
\text { procedure (two } \\
\text { envelope } \\
\text { system) }\end{array}$ & $\begin{array}{l}\text { Tenderers submit technical and financial proposals in two } \\
\text { envelopes; financial proposal is only opened and considered if it } \\
\text { attains minimum threshold score }\end{array}$ \\
\hline & $\begin{array}{l}\text { Proposal } \\
\text { procedure (two } \\
\text { stage system) }\end{array}$ & $\begin{array}{l}\text { Tender offers are invited from those that submitted acceptable } \\
\text { proposals based on revised procurement documents. } \\
\text { Alternatively, a contract is negotiated with the tenderer scoring } \\
\text { the highest number of points. }\end{array}$ \\
\hline & $\begin{array}{l}\text { Qualified } \\
\text { procedure }\end{array}$ & $\begin{array}{l}\text { A call for expressions of interest is advertised, and thereafter only } \\
\text { those who have expressed interest, satisfy objective criteria and } \\
\text { who are selected to submit tender offers, are invited to do so. }\end{array}$ \\
\hline & $\begin{array}{l}\text { Quotation } \\
\text { procedure }\end{array}$ & $\begin{array}{l}\text { Tender offers are solicited from not less than three tenderers in } \\
\text { any manner the organization chooses, subject to the procedures } \\
\text { being fair, equitable, transparent, competitive and cost effective }\end{array}$ \\
\hline & $\begin{array}{l}\text { Shopping } \\
\text { procedure }\end{array}$ & $\begin{array}{l}\text { Obtain three written or verbal quotes and confirm the lowest offer } \\
\text { once confirmed }\end{array}$ \\
\hline \multirow{2}{*}{ 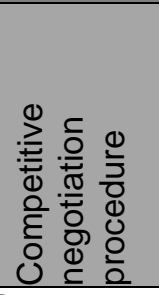 } & $\begin{array}{l}\text { Restricted } \\
\text { competitive } \\
\text { negotiations }\end{array}$ & $\begin{array}{l}\text { Tenderers who have expressed interest, satisfy objective criteria } \\
\text { and who are selected to submit tender offers, are invited and the } \\
\text { client evaluates offers and determines who may enter into } \\
\text { competitive negotiations }\end{array}$ \\
\hline & $\begin{array}{l}\text { Open } \\
\text { competitive } \\
\text { negotiations }\end{array}$ & $\begin{array}{l}\text { The employer evaluates the offers and determines who may enter } \\
\text { into competitive negotiations }\end{array}$ \\
\hline
\end{tabular}

Source: Draft International Standard ISO/DIS 10845 - 1 (2008) International Organization for Standardization (ISO) (2008)

Does South Africa have the potential to undertake world-class construction projects using different categories of non-traditional procurement systems? 
Even though South Africa is a developing country, construction-wise, it has the potential to undertake both public- and private-sector construction projects using the categorisation of universal procurement systems. This is evidenced by the empirical survey conducted by Grobler and Pretorius (1999). Their study has established that about $30 \%$ of the respondents agreed that the traditional procurement system has been the most used and favoured form of procurement system for housing-delivery projects in South Africa. These authors further indicated in their report that $62 \%$ of both building and civil engineering projects were delivered using the integrated type of procurement systems (design and build) and $8 \%$ of both building and civil engineering projects were implemented using other forms of non-traditional procurement systems, with construction management being the least-used form of procurement systems used.

Another empirical survey conducted by Mbanjwa and Basson (2003) indicates on a scale of 1 to 5 , with 1 indicating no knowledge and 5 indicating excellent knowledge, that the traditional procurement system was rated the most favoured form of procurement systems, followed by construction management (ranked $2^{\text {nd }}$ ), management contracting ranked $3^{\text {rd }}$; design and build (turnkey) ranked $4^{\text {th }}$; and design and manage including (build, operate and transfer) ranked $5^{\text {th }}$. However, the survey findings of Grobler and Pretorius (1999), Chege (April, 2001) and Mbanjwa and Basson (2003) indicate that some of the construction projects delivered locally used different categorisation and innovative procurement systems.

\section{FINDINGS}

The theory and literature review conducted during this study revealed that factors that influence the selection of procurement systems in South Africa are classified as internal and external factors. Factors from the internal environment were further grouped into client characteristics and project characteristics. Client characteristic factors were found to comprise artificial factors (variables) such as clients' level of knowledge, political and social consideration, familiarity with procurement system, competition, funding arrangements, government (public)/private sector project, and risk allocation. Project characteristics were found to be artificial factors (variables) such as size and technical complexity of the project, influence of the life cycle of the project, expedited project delivery, time, quality, and price certainty. Factors from the external environment comprised the following variables: market competition, information technology, regulatory environment, natural causes and globalisation.

The 20 variables (artificial factors) as shown in Table 2 below, obtained from the theory and literature review mentioned above, were further subjected to an empirical survey, based on the four-round Delphi survey method, which was used to obtain the participant's level of comprehension with regard to various procurement systems as utilised within the South African construction industry. Because of the large number of variables collected from Round 1, a multivariate method known as factor analysis was used in Round 2. This method analyses correlated but difficult to interpret variables into fewer conceptually meaningful and relatively independent variables.

\section{Analysis of Round 2}

A 5-point Likert scale was used to obtain the participant's opinions in Round 2, and the results of Round 2 were then descriptively and inferentially analysed. Descriptively, the means and standard deviation scores were computed in order to determine the variability of the spread of data as shown in Table 2 below. 
Table 2: The descriptive statistics of all the factors collected from Round 1

\begin{tabular}{|l|l|l|l|l|l|l|}
\hline No & Variables & Obs. & Min & Max & Mean & Std Dev. \\
\hline 1 & Client's level of knowledge & 19 & 1.000 & 5.000 & 4.105 & 1.449 \\
\hline 2 & Influence of the life cycle of the project & 19 & 1.000 & 5.000 & 2.895 & 1.696 \\
\hline 3 & Government/private sector project & 19 & 1.000 & 5.000 & 3.579 & 1.427 \\
\hline 4 & Political consideration & 19 & 1.000 & 5.000 & 3.368 & 1.707 \\
\hline 5 & Expedited project delivery/time constraints & 19 & 1.000 & 5.000 & 2.895 & 1.883 \\
\hline 6 & Corruption/self-enrichment & 19 & 1.000 & 5.000 & 4.053 & 1.433 \\
\hline 7 & $\begin{array}{l}\text { Size and technical complexity of the } \\
\text { project }\end{array}$ & 19 & 1.000 & 5.000 & 4.368 & 0.955 \\
\hline 8 & Funding arrangements & 19 & 4.000 & 5.000 & 4.158 & 0.375 \\
\hline 9 & Familiarity of procurement system & 19 & 1.000 & 5.000 & 3.947 & 1.129 \\
\hline 10 & Affirmative action/government policies & 19 & 1.000 & 5.000 & 3.158 & 1.740 \\
\hline 11 & Competition & 19 & 1.000 & 5.000 & 3.579 & 1.644 \\
\hline 12 & Risk allocation/reduction & 19 & 1.000 & 5.000 & 4.105 & 1.197 \\
\hline 13 & Client's specific requirements & 19 & 1.000 & 5.000 & 3.579 & 1.427 \\
\hline 14 & Client's budget/cash flow & 19 & 1.000 & 5.000 & 4.053 & 1.177 \\
\hline 15 & Lack of resources & 19 & 1.000 & 5.000 & 3.211 & 1.960 \\
\hline 16 & Markets/economic conditions & 19 & 1.000 & 5.000 & 3.316 & 1.336 \\
\hline 17 & Political influences/interferences & 19 & 1.000 & 5.000 & 3.579 & 1.427 \\
\hline 18 & Unemployment/lack of skilled labour & 19 & 1.000 & 5.000 & 3.737 & 1.327 \\
\hline 19 & Emerging technology & 19 & 1.000 & 5.000 & 3.368 & 1.707 \\
\hline 20 & Globalisation & 19 & 1.000 & 5.000 & 3.158 & 1.425 \\
\hline
\end{tabular}

Inferential statistics were also computed in order to determine whether all the participants had been drawn from the same population. The entire input dataset was subjected to two tests, namely Bartlett's test of sphericity and standardised Cronbach's alpha ( $\alpha$ ), and satisfactory results were produced, as shown in Table 3 below.

Table 3: Standardised Cronbach's alpha coefficient and Bartlett's test of sphericity

\begin{tabular}{|l|l|l|}
\hline \multicolumn{2}{|l|}{ Standardised Cronbach's alpha coefficient $(\alpha)$} & 0.756 \\
\hline \multirow{3}{*}{ Bartlett's test of sphericity } & Approx. chi-square & 76.37 \\
\cline { 2 - 3 } & DF & 19 \\
\cline { 2 - 3 } & Sig. & 0.0001 \\
\hline
\end{tabular}

Table 4: Eigenvalues, variability and cumulative variability before Varimax rotation

\begin{tabular}{|l|l|l|l|}
\hline Factors & Eigenvalues & Variability (\%) & Cumulative (\%) \\
\hline F1 & 4.989 & 24.947 & 24.947 \\
\hline F2 & 4.602 & 23.010 & 47.952 \\
\hline F3 & 2.475 & 12.375 & 60.332 \\
\hline F4 & 1.232 & 6.159 & 66.491 \\
\hline F5 & 1.124 & 5.620 & 72.111 \\
\hline F6 & 0.898 & 4.488 & 76.598 \\
\hline F7 & 0.760 & 3.801 & 80.400 \\
\hline F8 & 0.416 & 2.082 & 82.482 \\
\hline F9 & 0.226 & 1.130 & 83.611 \\
\hline F10 & 0.155 & 0.776 & 84.388 \\
\hline F11 & 0.045 & 0.223 & 84.610 \\
\hline F12 & 0.004 & 0.019 & 84.629 \\
\hline
\end{tabular}


W.D Thwala,

M.D Mathonsi,
Selection of procurement systems in the South African construction industry: An exploratory study

Figure 1: A scree test plot from principal factor analysis

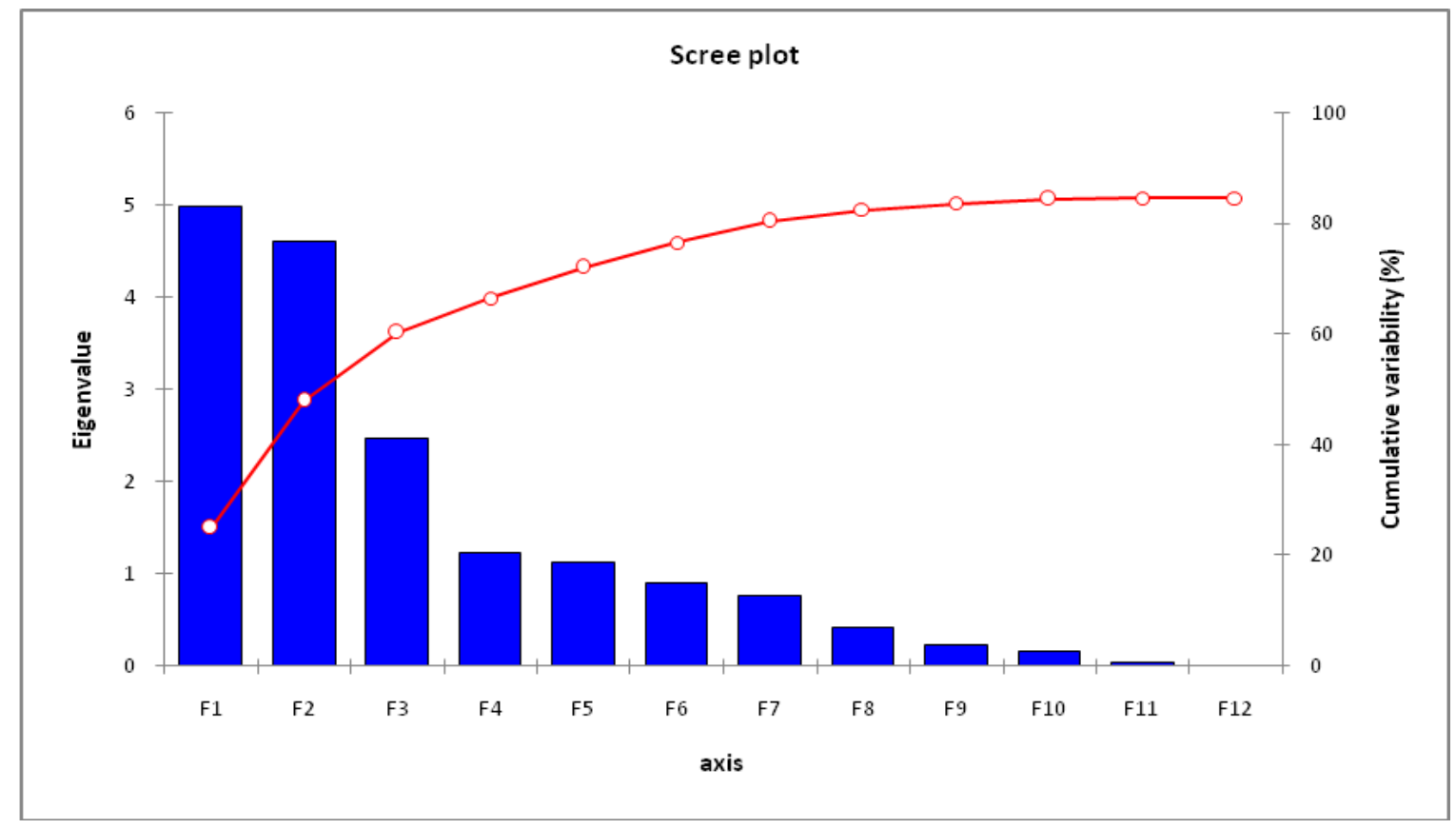

Table 5: Factor pattern (loadings) obtained after the initial extraction of data

\begin{tabular}{|c|c|c|c|c|c|c|c|c|c|c|}
\hline \multirow{2}{*}{$\begin{array}{l}\text { Variable } \\
\text { Code }\end{array}$} & \multicolumn{7}{|l|}{ Factors } & \multicolumn{2}{|c|}{ Communality } & \multirow[b]{2}{*}{$\begin{array}{l}\text { Specific } \\
\text { variance }\end{array}$} \\
\hline & $\mathrm{F} 1$ & F2 & F3 & F4 & F5 & F6 & F7 & Initial & Final & \\
\hline V1 & -0.764 & 0.432 & -0.099 & 0.061 & 0.273 & 0.154 & 0.013 & 0.997 & 0.883 & 0.117 \\
\hline V2 & 0.075 & 0.231 & -0.616 & 0.282 & 0.558 & 0.131 & 0.082 & 0.980 & 0.853 & 0.147 \\
\hline V3 & 0.613 & 0.532 & -0.253 & -0.094 & 0.025 & -0.241 & -0.252 & 1.000 & 0.853 & 0.147 \\
\hline V4 & 0.810 & 0.506 & 0.186 & 0.214 & -0.015 & 0.010 & -0.009 & 1.000 & 0.993 & 0.007 \\
\hline V5 & 0.878 & 0.115 & 0.006 & 0.042 & 0.035 & 0.362 & 0.070 & 0.997 & 0.923 & 0.077 \\
\hline V6 & 0.434 & 0.658 & -0.090 & -0.444 & -0.389 & -0.109 & 0.058 & 0.987 & 0.994 & 0.006 \\
\hline V7 & -0.085 & -0.083 & -0.526 & 0.252 & 0.060 & -0.004 & 0.000 & 0.969 & 0.357 & 0.643 \\
\hline V8 & 0.221 & -0.153 & -0.284 & -0.331 & 0.016 & 0.276 & -0.531 & 1.000 & 0.620 & 0.380 \\
\hline V9 & 0.140 & 0.018 & 0.222 & 0.134 & 0.197 & -0.323 & -0.415 & 0.870 & 0.403 & 0.597 \\
\hline V10 & 0.222 & 0.314 & -0.518 & -0.333 & 0.009 & 0.260 & 0.236 & 0.956 & 0.651 & 0.349 \\
\hline V11 & -0.628 & 0.487 & 0.420 & -0.082 & 0.187 & 0.212 & -0.163 & 0.995 & 0.921 & 0.079 \\
\hline V12 & -0.212 & 0.593 & 0.551 & 0.242 & -0.299 & 0.391 & 0.016 & 0.992 & 1.000 & 0.000 \\
\hline V13 & -0.592 & 0.698 & -0.275 & -0.064 & -0.109 & 0.005 & -0.163 & 1.000 & 0.955 & 0.045 \\
\hline V14 & -0.293 & 0.151 & 0.362 & -0.435 & 0.257 & -0.312 & 0.231 & 0.956 & 0.646 & 0.354 \\
\hline V15 & 0.135 & 0.587 & 0.529 & 0.170 & 0.277 & -0.073 & -0.022 & 0.990 & 0.754 & 0.246 \\
\hline V16 & 0.518 & 0.447 & -0.147 & -0.134 & 0.300 & -0.118 & 0.075 & 0.960 & 0.618 & 0.382 \\
\hline V17 & -0.592 & 0.698 & -0.275 & -0.064 & -0.109 & 0.005 & -0.163 & 1.000 & 0.955 & 0.045 \\
\hline V18 & -0.261 & 0.331 & -0.450 & 0.484 & -0.396 & -0.284 & 0.050 & 0.945 & 0.854 & 0.146 \\
\hline V19 & 0.810 & 0.506 & 0.186 & 0.214 & -0.015 & 0.010 & -0.009 & 0.991 & 0.993 & 0.007 \\
\hline V20 & -0.216 & 0.866 & -0.045 & -0.057 & 0.049 & -0.104 & 0.172 & 0.870 & 0.845 & 0.155 \\
\hline $\begin{array}{l}\text { Sum of } \\
\text { squares }\end{array}$ & 4.99 & 4.602 & 2.475 & 1.23 & 1.124 & 0.898 & 0.760 & & & \\
\hline $\begin{array}{ll}\% & \text { of } \\
\text { trace } & \end{array}$ & 24.95 & 23.010 & 12.375 & 6.15 & 5.620 & 4.488 & 3.801 & 72.11 & & \\
\hline
\end{tabular}




\section{Deriving factors and assessing overall fit}

The correlation matrices were factor analysed using principal factor analysis to produce factor loading which indicates the correlation between variables and the factors. It was established within the set of 20 variables that only five factors could be extracted for further consideration. The determination of the number of factors to be retained was based on the Kaiser criterion (Kaiser, 1969) and supplemented by Cattell's scree test plot (Cattell, 1966), which suggest that only those factors with eigenvalues greater than or equal to1.00 are retained for further consideration, and to drop all other factors with eigenvalues of less than 1.00 or all other factors that are located immediately after the break or elbow as they are considered to contain debris information as shown in Table 4 and Figure 1. Table 5 above shows the results of un-rotated factor matrix; the combined amount of variance explained by the factor solution in Table 5 is $72.11 \%$ which indicates that the variables are moderately related in each group of the five retained factors, which at the same time do not present a cleaner representation of significance of variables. It is for that reason that factor analysis cannot be stopped at the initial factoring stage because it makes it difficult to interpret these factors.

It can also be observed from Table 5 that a large number of communality indicates that a large amount of variance in a particular factor has been accounted for by the factor solution, whereas small communalities suggest that a considerable percentage of variance in a variable is not accounted for by other factors.

A graphical representation of variables before rotation is given in Figure 2.

Figure 2: Graphical representation of variables before rotation

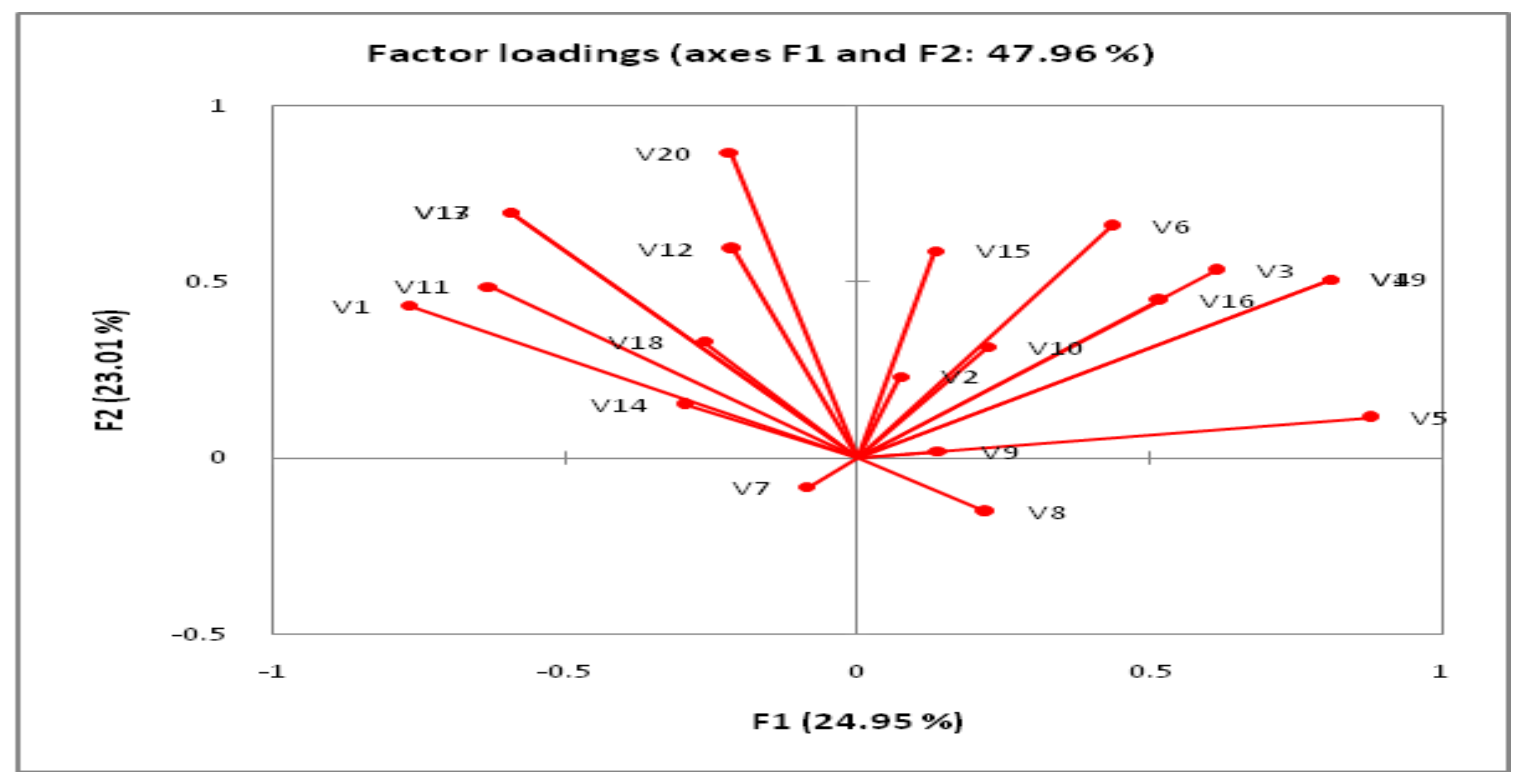

Figure 2 above indicates a two-dimensional distribution of factor loadings of Table 5 above. The plot shows the initial factor extraction with groupings of variables of similar characteristics on axes F1 and F2 of the 20 variables.

\section{FACTOR ROTATION}

Factor rotation is the process of holding the points constant and mainly rotating the axes. The purpose of this operation is to provide a more meaningful interpretation of the factor solution (http://www.qualtrics.co.za). In this study a Varimax rotation was employed, which is an orthogonal rotation which produces uncorrelated factors on the factor axis in order to maximise the variance of the squared loadings. After Varimax rotation, meaningful artificial factor loadings or variables that cross-loaded on more than one factor were deleted because they were considered to be deceitful measures of any one construct. Variables that were dropped from the factor analysis include V4, V6, V11, V12, V15 and V18 as shown in Table 6. 
Table 6: Factor pattern (loadings) obtained after Varimax rotation that cross-loaded on more than one factor

\begin{tabular}{|l|l|l|l|l|l|l|}
\hline Code & Variable description & D1 & D2 & D3 & D4 & D5 \\
\hline V1 & Client's level of knowledge & -0.339 & 0.791 & 0.107 & 0.173 & 0.277 \\
\hline V2 & Influence of the life cycle of the project & 0.214 & 0.178 & -0.166 & -0.068 & 0.848 \\
\hline V3 & Government/private sector project & 0.814 & 0.095 & -0.066 & -0.208 & 0.112 \\
\hline V4 & Political consideration & 0.944 & -0.137 & -0.082 & 0.267 & -0.068 \\
\hline V5 & Expedited project delivery/time constraints & 0.768 & -0.441 & -0.038 & -0.027 & 0.031 \\
\hline V6 & Corruption/self enrichment & 0.743 & 0.327 & 0.014 & -0.394 & -0.405 \\
\hline V7 & Size \& technical complexity of the project & -0.116 & 0.039 & -0.387 & -0.165 & 0.407 \\
\hline V8 & Funding arrangements & 0.092 & -0.179 & 0.073 & -0.459 & 0.076 \\
\hline V9 & Familiarity of procurement system & 0.123 & -0.124 & 0.130 & 0.271 & 0.073 \\
\hline V10 & Affirmative action/government policies & 0.378 & 0.222 & -0.037 & -0.548 & 0.183 \\
\hline V11 & Competition & -0.202 & 0.692 & 0.401 & 0.394 & -0.116 \\
\hline V12 & Risk allocation/reduction & 0.173 & 0.497 & -0.039 & 0.580 & -0.482 \\
\hline V13 & Client's specific requirements & -0.047 & 0.950 & -0.121 & -0.088 & 0.026 \\
\hline V14 & Client's budget/cash flow & -0.130 & 0.269 & 0.624 & 0.042 & -0.121 \\
\hline V15 & Lack of resources & 0.462 & 0.270 & 0.313 & 0.602 & -0.037 \\
\hline V16 & Markets/economic conditions & 0.695 & 0.062 & 0.173 & -0.112 & 0.264 \\
\hline V17 & Political influences/interferences & -0.047 & 0.950 & -0.121 & -0.088 & 0.026 \\
\hline V18 & Unemployment/lack of skilled labour & -0.023 & 0.453 & -0.749 & 0.030 & 0.060 \\
\hline V19 & Emerging technology & 0.944 & -0.137 & -0.082 & 0.267 & -0.068 \\
\hline V20 & Globalisation & 0.356 & 0.816 & 0.066 & 0.091 & 0.023 \\
\hline
\end{tabular}

\section{Interpretation and naming of surviving variables}

A 0.40 factor loading was used as a cut-off point (Stevens, 1986), therefore the surviving variables with factor loadings of 0.40 or higher (Stevens, 1986) were considered further for interpretation and naming. The interpretation and naming of factors implied that the remaining or surviving variables with high factor loadings and common conceptual meanings were grouped together to form a genuine independent factor. Table 7 provides a summary of rotated factor patterns. After the grouping, naming and interpretation, five newly established factors were identified and are considered to be significant factors that influence the selection of procurement systems in the South African construction industry.

Table 7: Significant factors obtained from the surviving variables after factor analysis

\begin{tabular}{|c|c|c|c|c|c|c|c|c|}
\hline \multirow{2}{*}{$\begin{array}{l}\text { Factor } \\
\text { Code }\end{array}$} & \multirow{2}{*}{$\begin{array}{l}\text { Variable } \\
\text { Code }\end{array}$} & \multirow{2}{*}{ Variable description } & \multicolumn{5}{|c|}{ Factor loadings } & \multirow{2}{*}{$\begin{array}{l}\text { Factor } \\
\text { scores }\end{array}$} \\
\hline & & & D1 & D2 & D3 & D4 & D5 & \\
\hline \multirow[t]{4}{*}{ D1 } & V3 & Political considerations & 0.944 & & & & & \multirow{4}{*}{3.269} \\
\hline & V4 & $\begin{array}{lll}\begin{array}{l}\text { Public } \\
\text { projects }\end{array} & \text { private } & \text { sector } \\
\end{array}$ & 0.814 & & & & & \\
\hline & V16 & $\begin{array}{l}\text { Market/economic } \\
\text { conditions }\end{array}$ & 0.768 & & & & & \\
\hline & V19 & Emerging technology & 0.743 & & & & & \\
\hline \multirow[t]{4}{*}{$\mathrm{D} 2$} & V13 & $\begin{array}{ll}\text { Client's } & \text { specific } \\
\text { requirements } & \end{array}$ & & 0.950 & & & & \multirow{4}{*}{3.501} \\
\hline & V17 & Political interferences & & 0.950 & & & & \\
\hline & V20 & Globalisation & & 0.816 & & & & \\
\hline & V1 & Client's level of knowledge & & 0.791 & & & & \\
\hline D3 & V14 & Client's budget/cash flow & & & 0.624 & & & 0.624 \\
\hline \multirow[t]{2}{*}{ D4 } & V8 & $\begin{array}{l}\text { Affirmative } \\
\text { Action/Government policies }\end{array}$ & & & & -0.548 & & \\
\hline & V10 & Funding arrangements & & & & -0.459 & & -1.007 \\
\hline
\end{tabular}




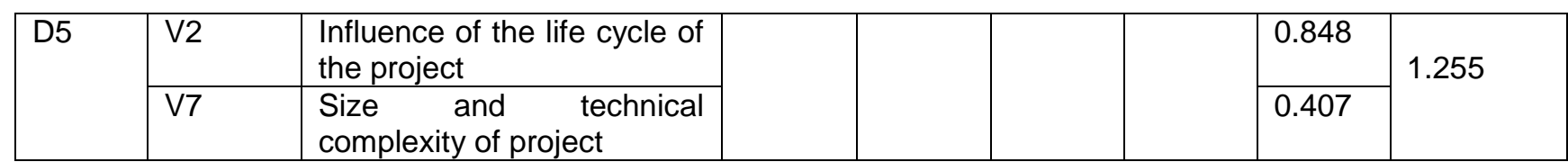

\section{Factor 1(D1): Socio-economic consideration}

Factor 1 (D1) is derived from four variables, namely political consideration (0.944), government (public) or private-sector project $(0.814)$, market or economic condition (0.768) and emerging technology (0.743). Three (3) variables have the highest loading of this factor relating to political and economic issues, therefore this factor can be referred to as 'socio-economic conditions'. This factor is assessed as reliable and valid at Cronbach's alpha coefficient $(\alpha)=0.910$ with a $2^{\text {nd }}$ highest factor score of 3.269 .

\section{Factor 2(D2): Client requirements}

Factor 2 (D2) for client requirements account for $23.27 \%$ of total variance, and variables loading on this factor include: client's specific requirements (0.950), political interferences (influences) (0.950), globalisation (0.816) and client's level of knowledge (0.791). Three variables that have the highest factor loadings seem to have common conceptual meaning which clients of the construction industry deem to be the prerequisites prior to making any procurement decision. Therefore, this factor can be referred to as 'client requirements'. This factor is also assessed as reliable and valid at Cronbach's alpha coefficient $(\alpha)=0.916$ with a highest factor score of 3.501 .

Factor 3(D3): Capital cost

Factor 3 (D3) explains $7.5 \%$ of the total variance with a factor loading of 0.624 ; however, it is difficult to interpret this factor, since only one variable loads on it. One thing clear about this factor is that it is a client- and cost-related factor. If this factor measures capital cost, it would be related to variables of Factor 2. More variables would need to be loaded on this factor to interpret it in a conclusive manner. It will, however, be referred to as 'capital cost'. Since questions were invalidly answered, they had to be omitted as being unreliable; Cronbach's alpha coefficient $(\alpha)=-0.759$. Factor $3(D 3)$ is the $2^{\text {nd }}$ lowest ranked with a factor score of 0.624 . It must, however, be borne in mind that a high or low degree of internal consistency of the Cronbach's alpha $(\alpha)$ does not directly address the major concerns about the data except for the fact that judges were not consistent when rating this factor.

\section{Factor 4 (D4): Procurement policy}

Factor 4 (D4) accounts for $9.409 \%$ of the total variance and is derived from two negative variables, namely affirmative action/government policy $(-0.548)$ and funding arrangements $(-0.459)$. Both of the two (2) variables relate to the Preferential Procurement Framework Act 5 of 2000 (CIDB, 2007) and the Broad-Based Economic Empowerment Act 53 of 2003 (CIDB, 2007). The former focuses on the participation of targeted enterprises and labour in the performance contract and the latter focuses on promoting social and economic goals, including developing criteria or strategies for entering into partnerships with the private sector. Therefore this factor can be referred to as 'procurement policy'. This factor had a Cronbach's alpha coefficient $(\alpha)=-0.088$. Factor 4 (D4) therefore has the lowest ranked factor score of -1.007 .

\section{Factor 5 (D5): Project characteristics}

Factor 5 (D5) is derived from two variables that explain $7.655 \%$ of the total variance, namely influence of the life cycle of the project $(0.848)$ and size and technical complexity of the project $(0.407)$. The two (2) variables loading onto this factor are those that are project related. Therefore, this factor can be referred to as 'project characteristics'. This factor is moderately reliable at Cronbach's alpha coefficient $(\alpha)=0.608$ with a factor score of 1.255 .

\section{Analysis of Round 3}

The utility value scores based of the various procurement systems vs. the 5 factors using a scale of 1 to 11 , with 1 representing least significant and 11 representing most significant. The results indicate that: 
Procurement policy (D4) with a utility value of 76.30 is the most significant factor

Project characteristics (D5) with a utility value of 74.55 is ranked $2^{\text {nd }}$ most significant factor

Socio-economic consideration (D1) with a utility value of 73.45 is ranked $3^{\text {rd }}$

Capital cost/cash flow (D3) with a utility value of 70.86 is ranked $4^{\text {th }}$

Client requirements (D2) is ranked $5^{\text {th }}$ with a utility value of 67.26

Further to the significance level of each factor, Kendall's coefficient of concordance $(W)$ was computed in order to assess the level of agreement among experts (judges). According to Legendre (2005), variables or experts are in total agreement when $\mathrm{H}_{0} \leq W \leq \mathrm{H}_{1}$, where one (1) indicates perfect agreement and zero ( 0$)$ no agreement. The test results of Kendall's coefficient of concordance $(W)=0.657$ for this study were computed, and virtually suggest a moderate level of consistency among the respondents.

\section{Analysis of Round 4}

Round 4 was basically a refinement of Round 3, except that the same utility value scores were re-sent to all the participants of Round 3 to re-evaluate their utility value scores. If a utility value score(s) different from those registered in Round 3 is observed, a mean utility value score different from the one in Round 3 was to be computed. However, all the participants in Round 4 committed to their initial scores.

\section{CONCLUSIONS AND RECOMMENDATIONS}

Based on the findings of this study, the South African construction industry has done well in implementing world-class projects successfully while utilising various procurement systems. Based on the findings of the literature review and empirical survey findings, it was established after factor analysis that five factors significantly influence the selection of procurement systems. The five factors in the order of importance in terms of their utility value scores are: procurement policy, project characteristics, socio-economic consideration, capital cost, and client requirements.

The study further revealed that, although the procurement choice or the utility value (level of satisfaction) by different procurement decision-makers is not in total agreement with each other, the utility value of any particular procurement type does not have a significant influence on the choice of procurement system. Based on the above, the following implementation measures are recommended: Construction planners, managers and all other stakeholders involved in procurement decision-making should formulate a systematic selection approach, as this will assist in eliminating unnecessary project demands.

Clear contractual arrangements should be set out right from the start as this will consequently assist with the determination of responsibilities of all project participants.

All clients of the construction industry, whether from the public or the private sector, should familiarise themselves with various procurement systems as this will assist them in making well-informed procurement decisions.

Client's actual needs, requirements, objectives and project goals must be accurately conveyed to the project team in order to enable the project team to develop a sound procurement strategy.

The procurement selection criteria should contain contingency measures in order to counteract any unforeseen circumstances, should these factors present themselves to the project.

A clear 'general strategy' be established at a very early (planning) stage of the project which will determine broadly what has to be done, how it must be done, by whom it must be done, where it must be done and when it must be done.

However, it must be borne in mind that the main focus of this study was not on investigating the most appropriate procurement selection criteria, but rather on investigating the factors that influence the selection of procurement systems. Therefore, further research that will focus on selection criteria of procurement systems in South Africa should be considered. 


\section{REFERENCES}

BENNET (2003) The management of construction: A project cycle approach, London: Butterworth-Heinemman.

BURKE, R. (2010) Fundamentals of project management: Tools and techniques, London: Burke Publishing.

CARTLIDGE, D. (2002) New aspects of quantity surveying practice, UK: Butterworth-Heinemann.

CATTELL, R.B. (1966) 'The scree test for the number of factors', Multivariate Behavioural Research, vol. 1, pp. 245-276.

CHEGE, L.W. (April, 2001) Private financing of construction projects and procurement systems: An integrated approval, Paper No. 259, Conference Proceedings, CIB World Building Congress, Wellington, New Zealand.

CONSTRUCTION INDUSTRY DEVELOPMENT BOARD (CIDB) (2005) Construction procurement practice guidelines \#A1: The procurement cycle, $2^{\text {nd }}$ edition, Pretoria, South Africa: CIDB.

CONSTRUCTION INDUSTRY DEVELOPMENT BOARD (CIDB) (2007) Construction procurement practice guidelines \#A2: Applying the procurement prescripts of the CIDB in public sector, $5^{\text {th }}$ edition, Pretoria, South Africa: CIDB.

DEPARTMENT OF PUBLIC WORKS (DPW) (May, 1999) White paper: Creating an enabling environment for reconstruction, growth and development in the construction industry in South Africa, Pretoria, South Africa: DPW.

INTERNATIONAL ORGANIZATION FOR STANDARDIZATION (ISO) (2008) Draft International Standard - ISO/DIS 10845-1: Construction procurement.

FACTOR ANALYSIS (n.d). Available from: http://www.qualtrics.com/wiki/index.php/FactorAnalysis (Accessed 23 October 2009).

GROBLER, K. and PRETORIUS, L. (1999) An evaluation of design-build as procurement method for building and civil engineering projects in South Africa, Johannesburg: Faculty of Engineering, Rand Afrikaans University.

MATHONSI, M.D. and Thwala, W.D. (2012) Factors influencing the selection of procurement systems in the South African construction industry, African Journal of Business Management Vol.6 (10), pp. $3583-3594$.

KAISER, H.F. (1960) 'The application of electronic computers to factor analysis', Educational and Psychological Measurement, vol. 20, pp. 141-151.

KERZNER, H. (2006) Project management: Systems approach to planning, scheduling and controlling, $9^{\text {th }}$ edition, New Jersey: John Wiley \& Sons, Inc.

Lam, E.W.M., Chan, A.P.C. and Chan, D.W.M. (2008). "Determinants of Successful Design-Build Projects". Journal of Construction Engineering and Management, Volume 134 (5) pp. 333-341, ASCE: USA.

LEADRA, O., AUSTENG, K., HAUGEN, T.I and KLAKEGG, O.J. (2006) Procurement routes in public building and construction projects, Journal of Construction Engineering Management, Vol. 132, Issue 7, pp. $689-696$.

LEGENDRE, P. (2005) 'Species associations: The Kendall coefficient of concordance revisited', Journal of Agricultural, Biological and Environmental Statistics, vol.10, pp. 226-245.

LOVE, P.E.D, SKITMORE, M.R. and EARL, G. (1998) 'Selecting an appropriate procurement method for the construction process: an empirical study', Construction Management and Economics, vol. 16, no. 2, pp.221-223. 
MASTERMAN, J.W.E. (2002) An introduction to building procurement systems, $2^{\text {nd }}$ edition, London: Spon Press.

MBANJWA, S. and BASSON, G. (2003) The use and effectiveness of construction management as a building procurement system in the South African construction industry, Pretoria: University of Pretoria, Faculty of Engineering, The Built Environment and Information Technology.

NATIONAL TREASURY PPP UNIT (2003) Public Finance Management Act 1999, Treasury regulation 16 of 76 (4). Available from: http://pppcentre.com

PILCHER, R. (1992) Principles of construction management, $3^{\text {rd }}$ edition, Maidenhead, UK: McGrawHill Book Company.

RAMEEZDEEN, R. and RATNASABAPATHY, S. (2006) 'A multiple decisive factor model for construction procurement system selection', Conference Proceedings of the $6^{\text {th }}$ Annual Research Conference, the Royal Institution of Chartered Surveyors, September, University College London, UK.

ROYAL INSTITUTE OF BRITISH ARCHITECTS (RIBA) (2000) Architecture and the changing construction industry, Available at: http://www.architecture .com/go/Architecture/Debate/change.html (Accessed date 21 April 2007) London: RIBA.

RWELAMILA, P.D. and MEYER, C. (1996) Procurement and balancing project parameters in Botswana and South Africa, Cape Town: University of Cape Town.

SOUTH AFRICAN NATIONAL STANDARDS (SANS) (2004) SANS 294:2004: Construction procurement processes, methods and procedures, $1^{\text {st }}$ edition, No. ICS 03.100.10, SANS ISBN Number: 062615684-X.

STEVENS, J. (1986) Applied multivariate statistics for the behavioural sciences. Hillsdale, NJ: Lawrence Erlbaum Associates.

TAN, W. (2007) Principles of project and infrastructure finance. London: Taylor \& Francis.

THE ROUND TABLE PROCESS (December, 2004) $A$ framework for developing effective procurement systems in developing countries: The Johannesburg declaration, World Bank Joint Round Table Initiative on Strengthening Procurement Capacities in Developing Countries, Round Table meeting held in Johannesburg, South Africa, from 30 November to 2 December 2004.

WALKER, D.H.T. and ROWLINSON, S. (2008) Procurement systems: A cross-industry project management perspective, London: Taylor \& Francis. 